
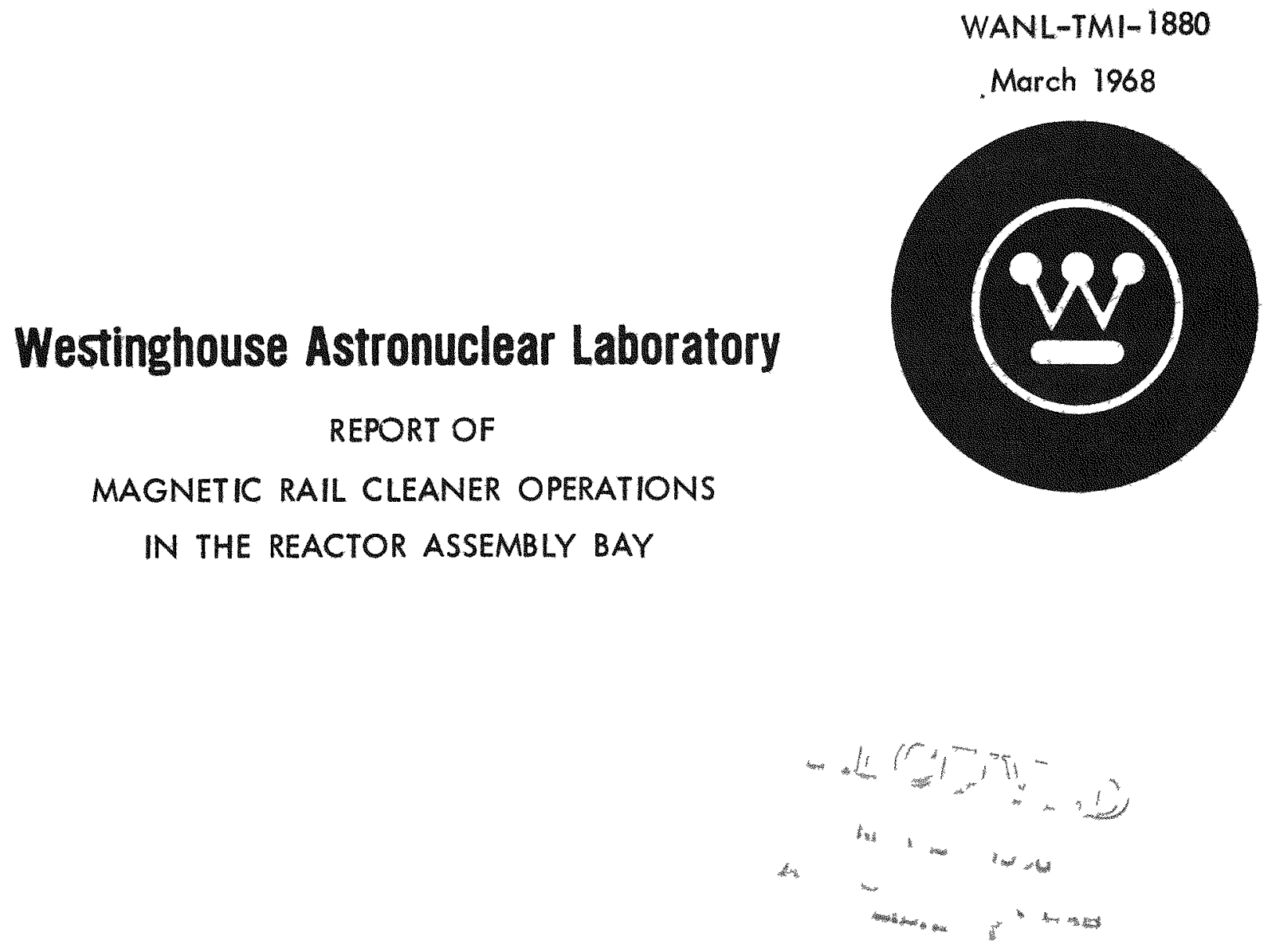

MASTER 


\section{DISCLAIMER}

This report was prepared as an account of work sponsored by an agency of the United States Government. Neither the United States Government nor any agency Thereof, nor any of their employees, makes any warranty, express or implied, or assumes any legal liability or responsibility for the accuracy, completeness, or usefulness of any information, apparatus, product, or process disclosed, or represents that its use would not infringe privately owned rights. Reference herein to any specific commercial product, process, or service by trade name, trademark, manufacturer, or otherwise does not necessarily constitute or imply its endorsement, recommendation, or favoring by the United States Government or any agency thereof. The views and opinions of authors expressed herein do not necessarily state or reflect those of the United States Government or any agency thereof. 


\section{DISCLAIMER}

Portions of this document may be illegible in electronic image products. Images are produced from the best available original document. 


\title{
REPORT OF \\ MAGNETIC RAIL CLEANER OPERATIONS \\ IN THE REACTOR ASSEMBLY BAY
}

\author{
Submitted By:
}
Westinghouse Electric Corporation
Astronuclear Laboratory
Pittsburgh, Pennsylvania 15236

Prepared By: C.T. Schacdel

C. T. Schaedel

NERVA Reactor Assembly

Approved By:

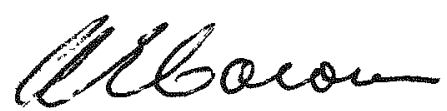

A. E. Cocoros, Manager

Manufacturing Operations
This report was prepared as an sccount of work sponsured by the United States Government. Neither the United States nor the Unthed States Energy Research and Development Administration, nor any of ther employees, nor any of their contractors, subcontractors, of their employees, nakes any warranty, express or implied, or assumes any legal liability or responsibility for the accuracy, completeness or usefulness of any information, apparatus, product or or usefuiness of any information, apparatus, product or
process disclosed, or represents that its ase would not infringe privately owned rights.
INFORMATION CATEGORY

UNCLASSIFIED

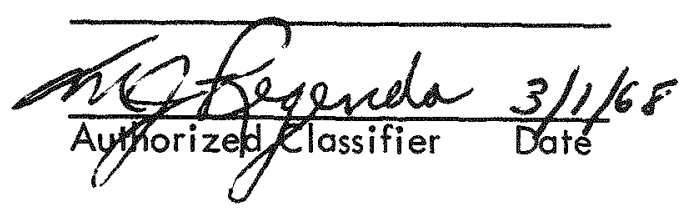


(2) Astronuclear

\section{LIST OF FIGURES}

Figure 1. Photograph of Magnetic Rail Cleaner Installed on the Crane in Reactor Assembly................................ 3

Figure 2. Installation of Magnetic Rail Cleaner..................... 4

Figure 3. Circuit Diagram of Magnetic Rail Cleaner................... 5

Figure 4. Photograph of Magnetic Rail Cleaner after Six Months in Service ........ 6 


\section{INTRODUCTION}

The magnetic particle catcher described in this report was evolved from an idea first given to Mr. A. E. Cocoros, Manager, Manufacturing Operations by Mr. T. J. Murrin, Vice President, Aerospace, Defense and Marine Group, Westinghouse Electric Corporation. A similar device is in use at the Westinghouse Muncie plant where it prevents magnetic particle contamination of sensitive assemblies.

In the Reactor Assembly Bay this device catches magnefic particles from the crane wheels and rails, eliminating the probability of steel particles falling in the vacinity of the reactor or the pressure vessel assembly. One of its features is a special tray which can be turned to permit cleaning the assembly. A wear-saving time delay relay is also incorporated.

This magnetic particle catcher has worked exceptionally well and is recommended for use in other facilities to prevent particulate contamination and to improve the life of crane wheels and rails. 
(2. Astronuclear

WANL-TMI-1880

Description

The electromagnetic rail cleaner for overhead cranes shown in Figure 1 was supplied by Magnetic Devices Incorporated for installation in the overhead crane in the Reactor Assembly Bay in Building 6A. The installation view, Figure 2, shows the support arms and springs which permit lateral and vertical movement of the guide rollers. Track allignment is kept in this way, and the magnetic fields are located to provide the best capturing forces.

Power to operate the electromagnet is supplied from outlets on the crane truss and is connected to the coils through a power relay (see Figure 3). The operating coil on the power relay is in turn controlled by a time delay relay which prevents power relay chatter and allows the track cleaner to operate for a short time (about 30 seconds) after the crane is stopped. The operating sequence is set by the crane controller which causes the trolley brake to be energized and the power relays to close.

\section{Operating Experience}

The magnetic rail cleaners were first installed in September 1966 with little trouble and in the manner described by Magnetic Devices Incorporated. The result of the first six months of operation is shown in Figure 4 where the trapped metal flakes can be seen hanging on the under side. These were easily removed by sliding the pivoted aluminum cover plate aside and catching the particles as they fell. The other magnetic surfaces were cleaned by wiping with cleaning cloth and by touching the most tenacious particles with the gummed side of masking tape.

The only problem with this unit occurred when the guide wheels wore out and were replaced with similar units made in the WANL Works Engineering Shop. Since then the operation has been troublefree. 


\section{(2.) Astronuclear}

WANL-TMI- 1880

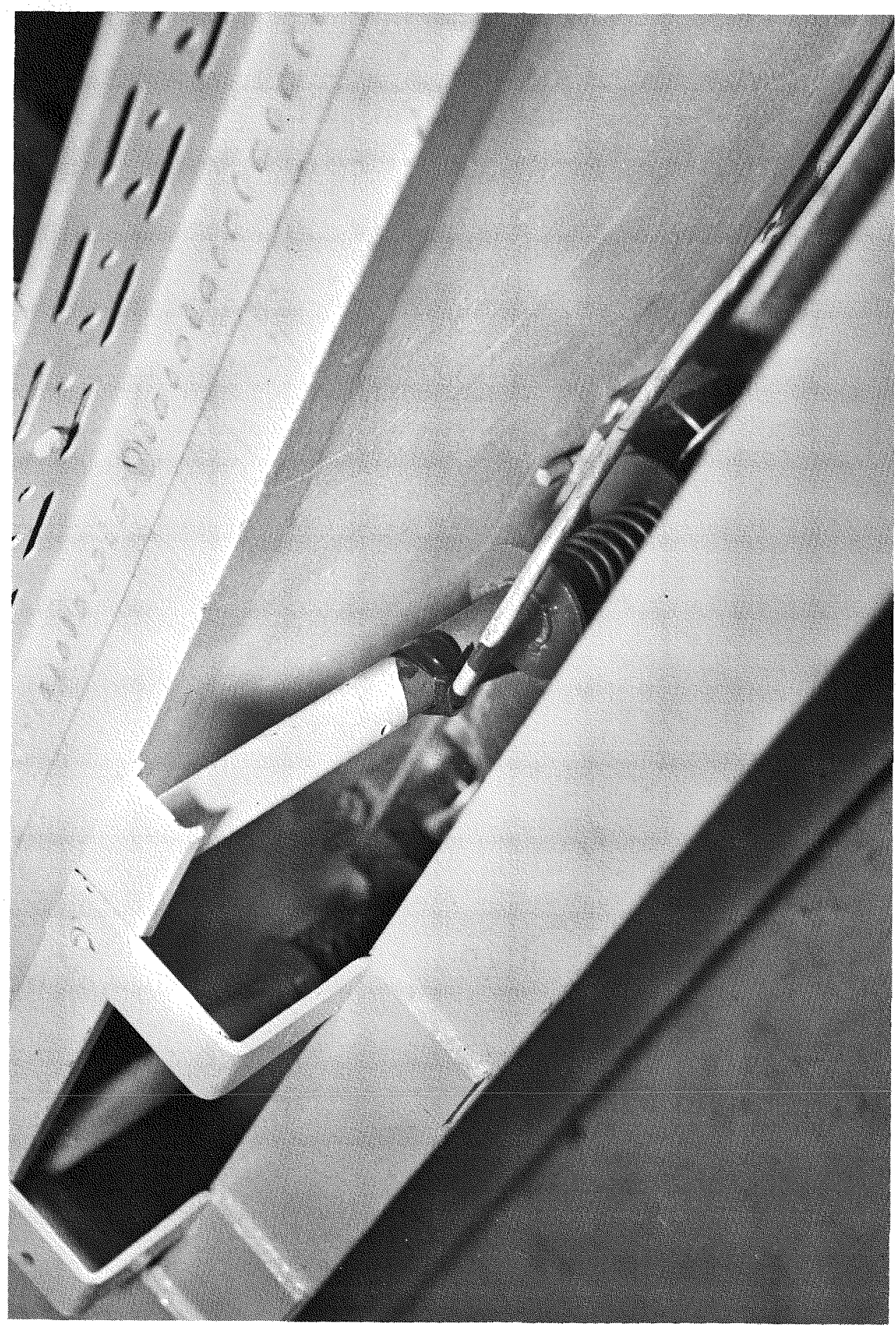

Figure 1. Photograph of Magnetic Rail Cleaner Installed on the Crane in Reactor Assembly 


\section{(2) Astronuclear Laboratory}

WANL-TMI- 1880

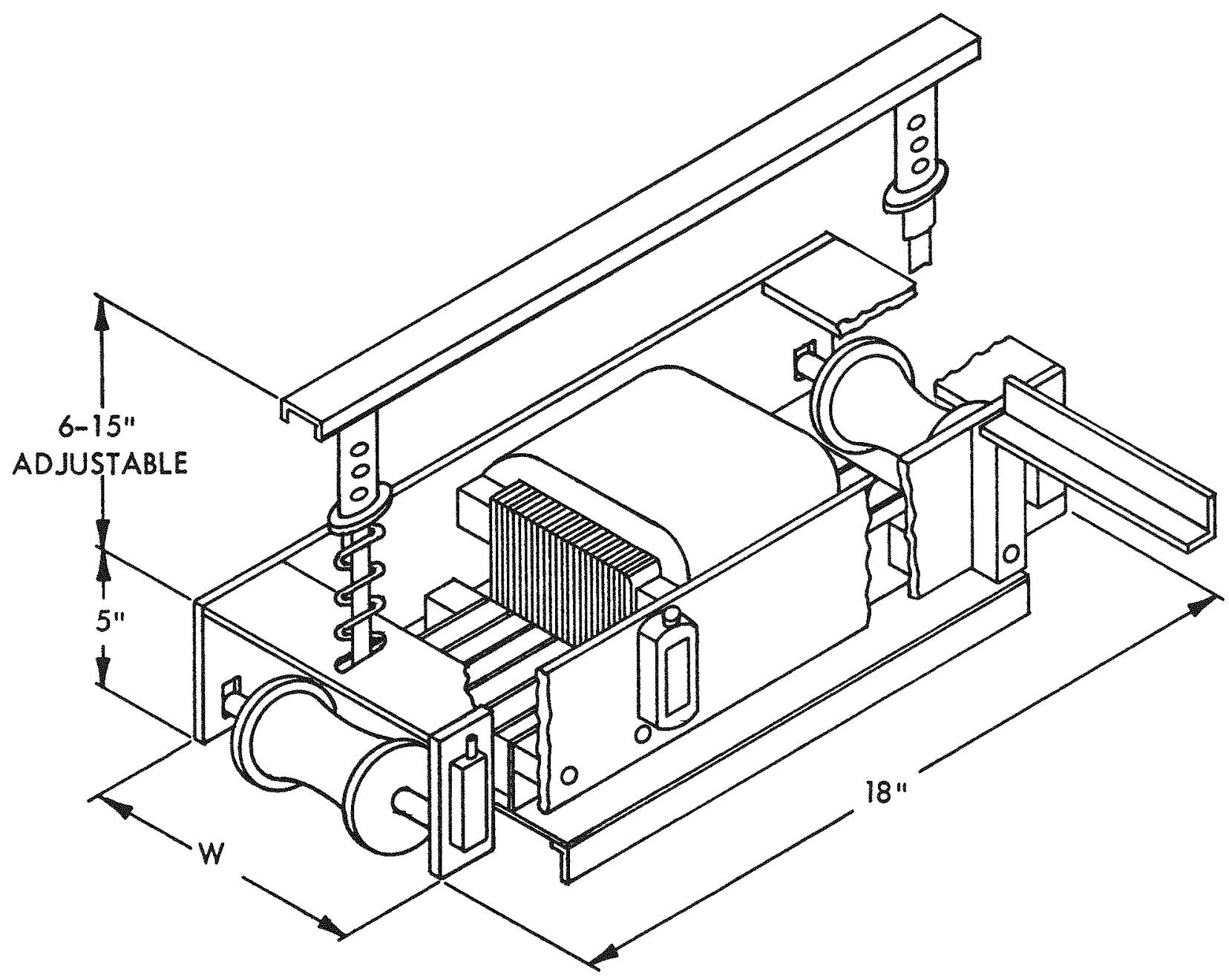

$612325-2 B$

Figure 2. Installation of Magnetic Rail Cleaner 


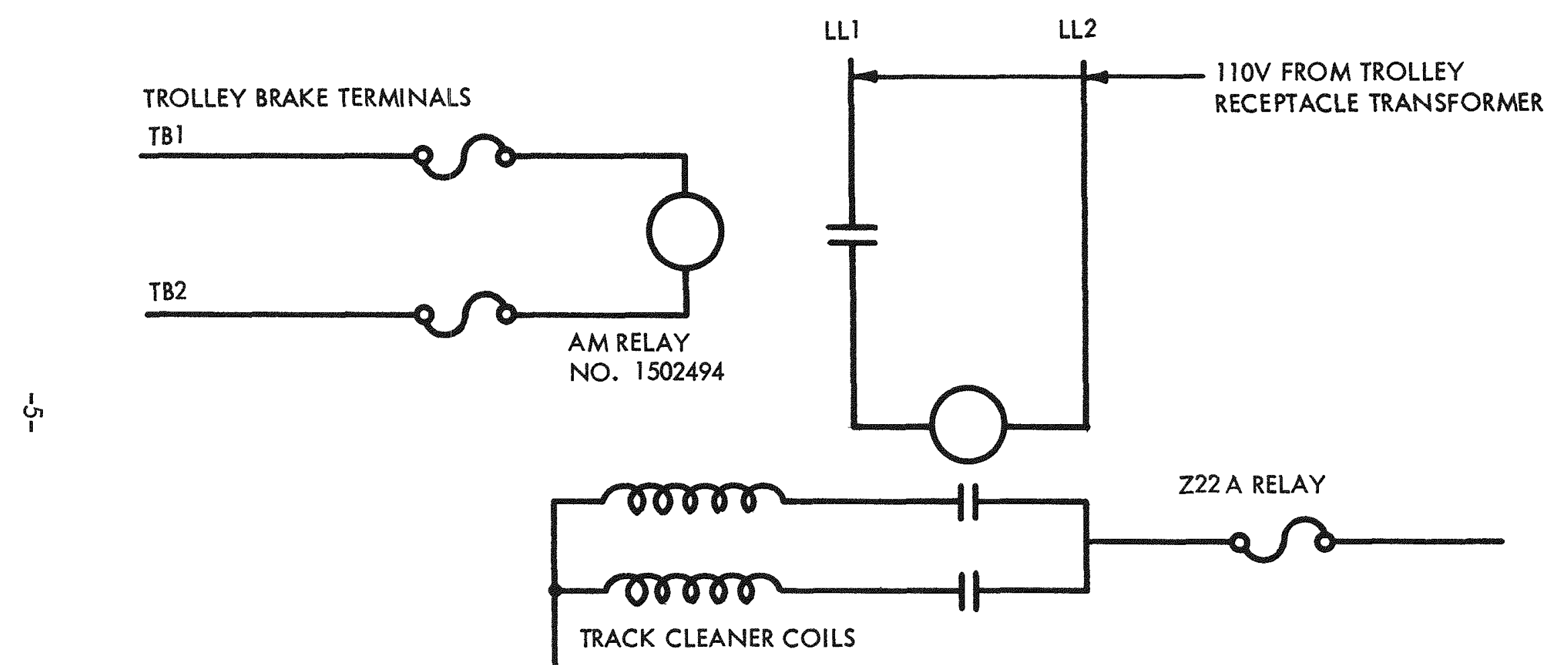

IIOV FROM TROLLEY RECEPTACLE TRANSFORMER

Figure 3. Circuit Diagram of Magnetic Rail Cleaner 


\section{(2. Astronuclear Laboratory \\ WANL-TMI-1880}

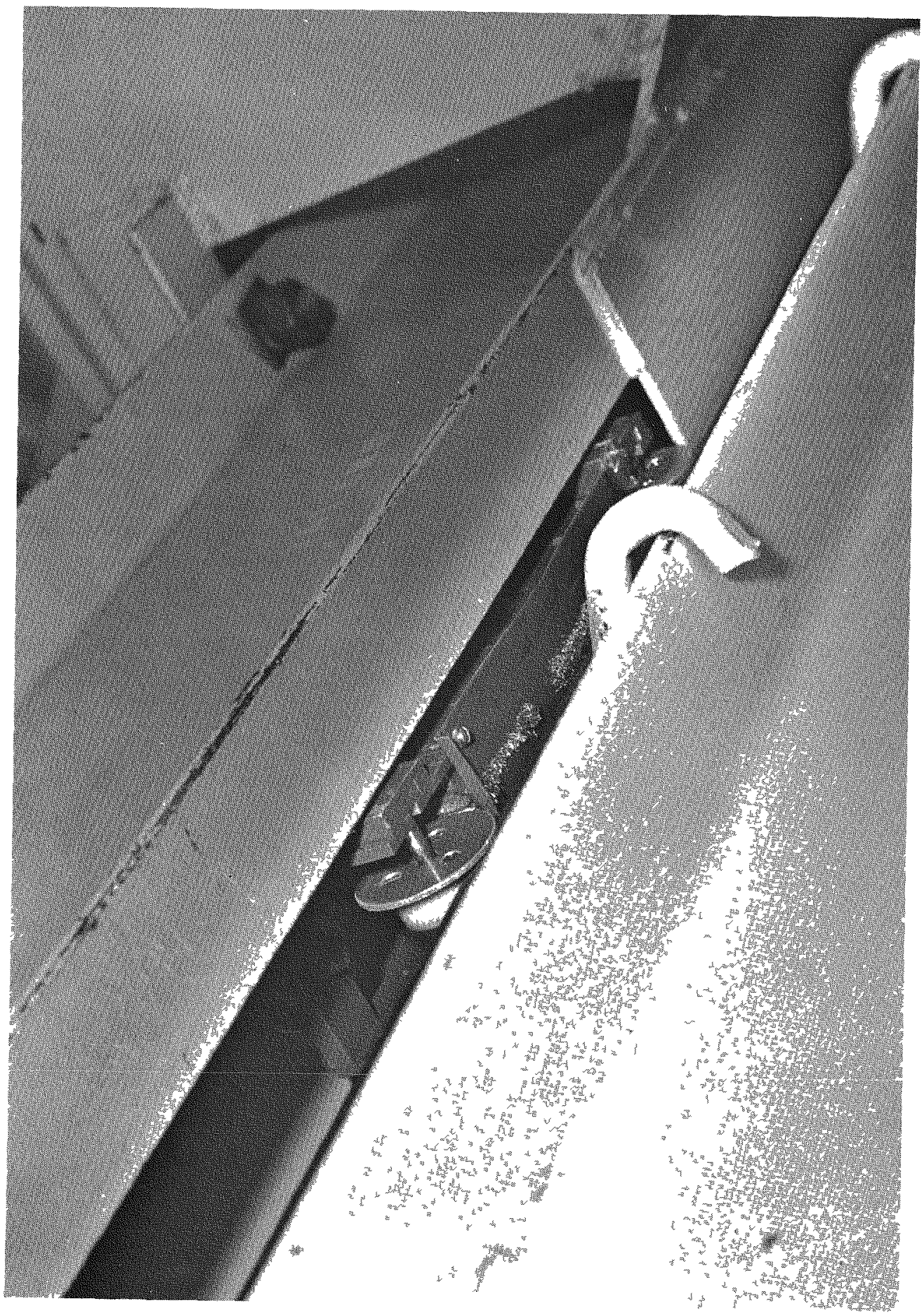

Figure 4. Photograph of Magnetic Rail Cleaner after Six Months in Service 
(2) Astronuclear

Laboratory

WANL-TMI-1880

In March 1968, after approximately $1-1 / 2$ years in service, the magnetic rail cleaners are still in continuous operation. The latest cleaning after six months of service resulted in removing approximately an ounce of chips and flakes which otherwise would have fallen off to endanger operations below. It is felt that this demonstrates the effectiveness of these devices and supports the decision to use them in the Reactor Assembly Laboratory. 